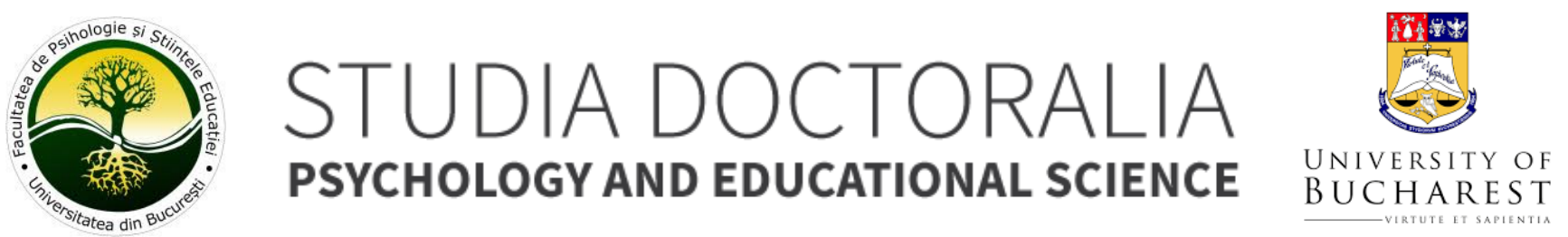

\title{
The relationship between neuroticism and job satisfaction. The mediating role of affect ${ }^{1}$ Georgiana Alexandra Olteanu \\ ${ }^{2}$ Andreea Corbeanu \\ ${ }^{1} 42$ Organizational Assessment, ${ }^{2}$ University of Bucharest, Department of Psychology
}

\section{ARTICLE INFO}

\section{Article history:}

Received 18-May-2018

Accepted 20-Sptember-2018

Available online 01-October-2018

This article should be cited as: Olteanu, G. A, Corbeanu, A. (2018). The relationship between neuroticism and job satisfaction. The mediating role of affect. Studia Doctoralia. Psychology and Educational Science, 15, 65-74.

This is an open access article under the CC BY license (http://creativecommons.org/licenses/by/4.0/).

Corresponding author at: 42 Organizational Assessment, Romania, Icoanei Street, no 6A, Bucharest

E-mail address: alexandra.olteanu@shl.ro
ABSTRACT

The present study aims to identify the extent to which positive and negative affect mediate the relationship between neuroticism and job satisfaction. A number of 117 participants, employees of different companies and industries participated in this study. The results are in favor the studies' hypothesizes, suggesting that the relation between neuroticism and job satisfaction is fully mediated by negative affect and partially mediated by positive affect. Finally, limitations, implications and directions for future research are discussed.

Keywords: job satisfaction, neuroticism, positive affect, negative affect

\section{INTRODUCTION}

The current research aims to identify the extent to which negative and positive affect mediate the relationship between a personality trait, in this case neuroticism, and job satisfaction.

Job satisfaction is one of the topics of great interest historically, both to practitioners, as well as to organizational researchers. Viewed as a positive emotional state, generated by one's subjective assessment of workplace experiences (Locke, 1979), job satisfaction becomes a topic of interest because it is strongly tied to performance, studies suggesting that a happy and satisfied employee is a productive and high-performing one (Organ \& Ryan, 1995). Moreover, job satisfaction has also been linked with workplace behaviours, such as citizenship behaviours, absenteeism and turnover intent (Thirulogasundaram \& Sahu, 2014), lateness, substance abuse and early retiring (Hulin, 1991).

In light of the above, regarding job satisfaction, it becomes increasingly clear that understanding this concept and its links with other concepts is crucial in understanding one's workplace behaviour, as well as improving the organizational quality of life. 
Among the most popular definitions of job satisfaction is the one advanced by Locke (1976), which describes it as an emotional state, positive or pleasant, which results from the assessment of one's workplace as well as their work experiences. Thus, Locke's definition includes both the cognitive part of work satisfaction, namely the „assessment” the individual makes, as well as the affective component- the emotional state. This interpretation has also been supported by other researchers, although it has been observed that most studies focused on the cognitive facet of the construct, thus ignoring, almost completely, the affective one (Brief, 1998). This approach has been supported by the cognitive theories of emotions and emotional theories of cognition, which suggest that affect and cognition are intercorrelated, thus when thinking about the workplace, we have both emotions associated with out thoughts, and when we feel anything in regards to our workplace, we are also thinking about it (Reisenzein \& Schönpflug, 1992; Smith-Lovin, 1991). The current paper contributes through bringing the affective aspect of work satisfaction under scrutiny.

\section{Neuroticism and work satisfaction}

Regarding the causes of work satisfaction, there is a string of theories which have tried to explain them. They can be divided into three categories, namely situational theories - which view the nature of one's work and other aspects related to the work environment as causes of work satisfaction; dispositional theories - which view one's personality as the main source of work satisfaction; and interactive theories- which view the source of workplace satisfaction as a mix between personal and environmental factors (Judge et al., 2001).

Although interindividual differences regarding workplace satisfaction have been observed ever since the beginnings of studying this concept, the dispositional approach is the most recent and the least studied, out of the three types of theories. It was only in the '80s that research following this lead took off, becoming one of the most popular research frameworks for job satisfaction (Staw, Bell \& Causen, 1986).

Since then, numerous theories attempted to offer a deeper understanding of personality, and thus a trait named neuroticism has emerged, in one way or another, across most such theories. Neuroticism refers to the degree of emotional stability and self-regulation a person has (Barrick \& Mount, 1991). It reflects the degree in which an individual tends to experience negative emotions, as fear, sadness, shame, anger, blame and contempt. Neuroticism should be viewed as an homogenous trait, composed of various distinct aspects, which are strongly interlinked, such as: anxiety, depression, shyness, lack of control and vulnerability (Costa \& McCrae, 1992).
The concept of neuroticism describes those individuals who have strong neurotic crises, with a pronounced emotionality, having fears, anxiety or depression; individuals with a constant need of emotional support. At high scores, neuroticism describes individuals who react emotionally very easily, perceiving at a high emotional intensity events which others are not affected by; individuals who tend to construe ordinary situations as threatening, and to transform frustrations into inescapable difficulties (Smith \& MacKenzie, 2006). The emotional reactions of these individuals tend to persist over long periods of time, which means they are often "down in the dumps". Emotional control deficiencies may lead to impairment of cognitive abilities, decision making or tolerance to stress. Moreover, people with high neuroticism are oftentimes self-critical, more sensitive to others' critique and experience inadequacy (Watson, Clark, Harkness, 1994). On the other hand, individuals with a low level of neuroticism are harder to upset, and are not so emotionally receptive. They tend to be more calm, more emotionally stable and not to have lasting negative emotional states (Brief, 1998).

According to researchers who have studied the emotional implications of neuroticism, a high level of it correlates with a greater level of psychological stress, emotional instability and maladjustment (Costa \& McCrae, 1992). Some authors suggest that neuroticism works as a warning system, which is triggered when there is the perception of uncertainty in one's environment, and it tends to interfere with one's ability to adapt. Ergo, individuals with a high level of neuroticism are considered less predisposed to control their impulses and face stress well. At the workplace, a high level of neuroticism describes emotionally unstable individuals, more predisposed to negative affect (Costa \& McCrae, 1985). Thus, in a professional context, these individuals display more negative emotions, which mirror negative attitudes towards the workplace, and a higher level of workplace stress (Newbury-Birch \& Kamali, 2001).

Regarding the link between personality traits and work satisfaction, the data provided by a meta-analysis published in 2002 (Judge et al., 2002) claim that neuroticism correlates strongest and most consistently with work satisfaction $(r=$ .29), followed by conscientiousness ( $r=.26)$, extraversion ( $r$ $=.25$ ). Connections with neuroticism have been highly researched over the years, and results are similar to the ones described by Judge et al. This fact has been attributed to the claim that emotional stability, albeit a low level of neuroticism, and extraversion are key components of a "happy personality" (DeNeve \& Cooper, 1998). Therefore, the general consensus is that the factors which lead emotionally stable and extravert individuals to be happy in their private lives, will have the same influence over their lives in the workplace (Tokar, Fischer, \& Subich, 1998). 


\section{The role of positive and negative affect in regards to neuroticism and workplace satisfaction}

Emotional experiences are a frequent topic of study in the scientific community, and are approached through the 2 dominant dimensions: positive and negative affect. These factors have been identified both through interindividual as well as intra-individual analyses, even across various languages and cultures (Meyer \& Shack, 1989).

Although the two facets of affect, positive and negative, may seem as the ends of a continuum, strongly negatively correlated, they are considered instead two very distinct concepts, albeit correlated. This approach has been highly debated, factor analysis studies suggesting two independent factors (Watson, 1988), which share a moderate, negative correlation of -.30. A person is capable of expressing both positive and negative affect, some intense and some low, or both of them of a low intensity (Naragon \& Watson, 2009). Regarding the stability of these concepts over time, as well as their link to various existential contexts, Naragon \& Watson (2009) have discovered that affect is moderately stable cross-situationally and over time.

Thus, taken separately, positive affect is seen as the degree in which a person feels active, enthusiastic, alert. A high level of positive affect describes a state of strong energy, focus, engagement, while a low level may be interpreted as sadness and lethargy (Watson, Clark \& Tellegen, 1988). Studies confirm that positive general emotional disposition leads to thinking, feeling and acting in ways which promote both gathering of resources as well as engagement when it comes to pursuing one's goals (Elliot \& Thrash, 2002; Lyubomirsky, 2001). An individual who has a positive mood will perceive and interpret life contexts as favourable and desirable (Lyubomirsky, King \& Diener, 2005). Other characteristics associated with positive affect are also self-trust, optimism and perceived self-efficacy.

On the other hand, negative affect is the level of suffering and inconvenience, which contains various aversive moods, such as anger, guilt, disgust, contempt on high levels, and calm and serenity on low levels.

As traits, negative and positive affect have been linked to the two big personality dimensions, namely extraversion and neuroticism. A link between them and the psychodynamic and psychobiological construct of sensitivity to punishment and reward has also been discovered. Moreover, it seems that, both as states as well as traits, positive and negative affect are major traits which help differenciate between depression and anxiety (Tellegen, 1985). Recent studies show that relationships between extraversion and negative affect, as well as between neuroticism and positive affect are not necessarily small or insignificant, but rather visible under certain circumstances
( $\mathrm{Ng}, 2009)$. Thus, it seems that both neuroticism and extraversion correlate with both positive and negative affect. Withal, it seems that personality has a "top-down" influence over the whole construct. Studies show that neuroticism and extraversion are directly responsible for regulating individual differences regarding positive and negative affect (Costa \& McCrae, 1980). Additionally, it seems that personality influences affect in the long term, through the predisposition it induces towards involvement in actions which favour either positive or negative affect (McCrae \& Costa, 1991). Some studies promote the existence of a negative, significant correlation between neuroticism and happiness (Cheng \& Furnham, 2003). Other, cross-cultural studies, have examined the differences between the East and the West, more specifically between China and the United Kingdom, and state that extraversion and neuroticism are key predictors of happiness, and can account to as much as half of its variance (Furnham \& Cheng, 1999). More recent studies offer additional proof to this assumption, that personality traits are antecedents of subjective well-being. Thus, it has been concluded that neuroticism has a negative, indirect impact on well-being and life satisfaction, through predisposing one to psychological stress and physical health problems (Gale, Booth, Mttus, Kuh, \& Deary, 2013).

When independently studied among other variables, studies have yielded interesting correlations. For example, negative affect has been correlated with self-reported stress and low coping, unsatisfactory health and a high frequency of unpleasant events, while positive affect has been linked to social activism, satisfaction and a high frequency of pleasant events (Clark \& Watson, 1988).

The other perspective, the temperamental one, claims that individuals who have a high level of negative affect are more sensitive to negative stimuli, and react in a more extreme manner when experiencing negative events. Thus, negative events which happen in a professional context, even if occurring with approximately the same frequency for all employees, generate additional negative affect for these kinds of individuals, ultimately leading to a decrease in job satisfaction.

On the other hand, individuals who tend to have more positive affect, think and act towards resource building and engagement in accomplishing their objectives (Elliot \& Thrash, 2002). They tend to interpret more of their experiences as desirable and to favour the positive aspects of life. Similarly, they also regard themselves and their own abilities more positively. In a professional context, such traits are characteristic to those individuals who develop resources and relationships with work colleagues, tend to be more confident in their abilities to finish tasks and are less influenced by negative events, all leading to a higher level of work satisfaction. 
There is also research which has studied the link between affect and work satisfaction. For example, Levin \& Stokes (1989) have examined a sample of 315 participants from a multinational corporation, and noticed that negative affect is an important predictor of work satisfaction. Judge (1993), in a study of medical personnel, claims that the link between lack of satisfaction and turnover intention is stronger for those who have a high level of negative affect.

A meta-analysis published in 1998 (Judge et al.) concluded that there is a .52 positive correlation between positive affect and job satisfaction, after examining 29 studies on this topic. Moreover, the same study discovered a -.40 correlation between negative affect and work satisfaction, in light of examining an additional 49 studies. Thus, it seems that job satisfaction is related both to positive and negative affect. The frequency of displaying negative affect is a more powerful predictor of work satisfaction than the intensity of the positive affect experienced by an individual (Fisher, 2000).

Starting from these research topics selected from the scholarly literature, our research hypotheses are as follows:

$\mathrm{H} 1$ : Negative affect mediated the relationship between neuroticism and job satisfaction.

$\mathrm{H} 2$ : Positive affect mediates the relationship between neuroticism and job satisfaction.

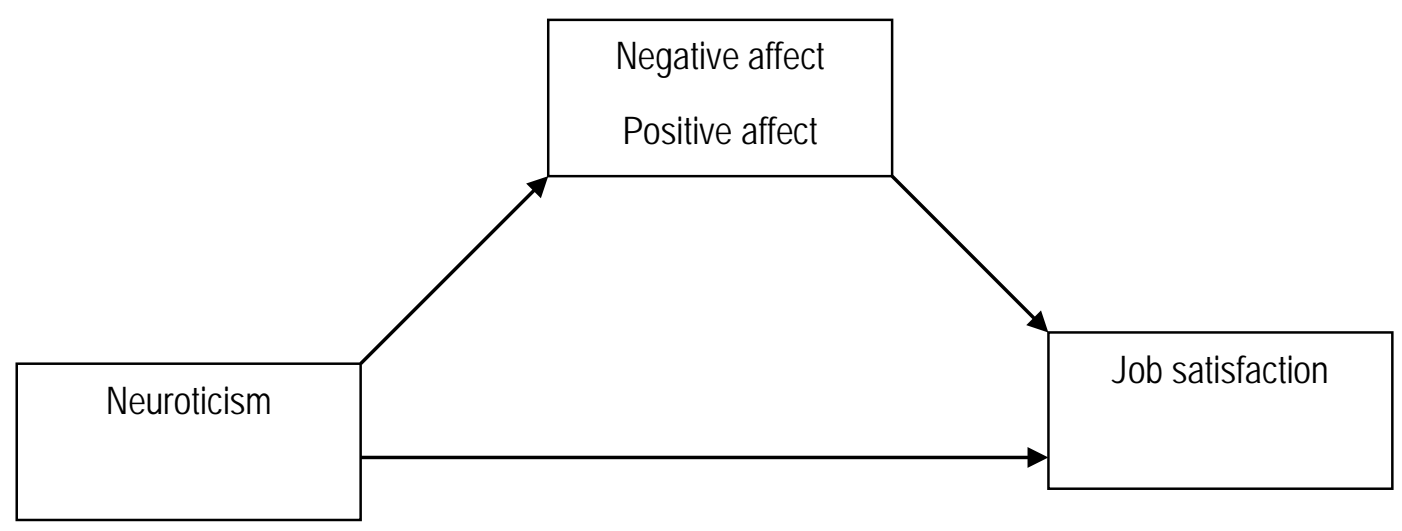

Figure 1. Mediation model

\section{METHODOLOGY}

\section{Participants and procedure}

Participation in this study was voluntary, ensuring the confidentiality of the obtained data. In the end, information from 117 participants (17\% males and $83 \%$ females), aged between 22 and 57 years old ( $M=28.2 ; S D=7.6)$ was gathered. The participants are employed either in Bucharest or accross Romania, having various jobs in fields such as medicine, finance, education, public health services. The only inclusion criteria for this study has been employment. Data has been collected online.

\section{Instruments}

Personality - Neuroticism. For measuring personality dimensions, more specifically neuroticism, a 30 IPIP item questionnaire has been used (Goldberg, 1996).

Exemplu de item alpha cronbach.
Positive and negative affect scale. The PANS Scale (Watson, Clark \& Tellegen, 1988) measures an individual's dominant disposition. It has 20 nouns describing various emotions, which can be grouped into a positive affect (AP) scale, which reflects the degree in which individuals feel active, enthusiastic and alert. The other dimension, namely negative affect (AN), points to a state of distress, inconvenience, including various aversive moods, such as anger, contempt, guilt, fear, nervousness; low AN scores indicate a state of calm, content, serenity. Internal consistency coefficients are .80 for the positive affect scale and .84 for the negative affect scale.

Job satisfaction scale. For evaluating job satisfaction, a measuring tool created by Judge et al. has been used- Brief Job Satisfaction Measure II (Judge, Locke \& Durham, 1998). This scale contains five affirmations regarding one's happiness with one's work or workplace, such as "I dislike my current workplace so much that every work day seems endless" (. alpha)

\section{RESULTS}


After the data collection phase has been completed, the information obtained has been analyzed using SPSS 20 (Statistical Package for the Social Sciences) and SEM (Structural Equation Modelling). Firstly, a descriptive analysis of the data has been generated, as is presented in Table 1.

Table 1. Means and standard deviations for the research variables ( $N=117)$

\begin{tabular}{lccc}
\hline & $M$ & SD & $a$ \\
\hline Job satisfaction & 19,26 & 3,96 &, 84 \\
Neuroticism & 29,44 & 9,21 &, 86 \\
Positive affect & 34,26 & 6,80 &, 86 \\
Negative affect & 19,33 & 7,18 &, 89 \\
\hline
\end{tabular}

Note: $\quad(\mathrm{N}=117) ; \mathrm{M}=$ mean; $\mathrm{SD}=$ standard deviation; $\alpha=$ Cronbach alfa coefficients

Table 2. Correlations between the research variables $(N=117)$

\begin{tabular}{lcccccc}
\hline Variable & M & SD & 1 & 2 & 3 & 4 \\
\hline 1. Job satisfaction & 19.26 & 3.96 & & & \\
2. Neuroticism & 29.44 & 9.20 & $-.35^{* *}$ & & \\
3. Positive affect & 34.26 & 6.79 & $.488^{* *}$ & $-.50^{* *}$ & \\
4. Negative affect & & & & & \\
\hline Note: Fidelity coefficients (a coefficients) are written in bold, diagonally; ${ }^{*} p<.05$ (two-tailed); ${ }^{* *} p<.01$ (two-tailed)
\end{tabular}

As is visible in Table 2, there are significant, positive or negative correlations between all the research variables. Thus, the analysis moved on to testing the actual research hypotheses.

For the first hypothesis, we have tested the mediator effect of negative affect on the relationship between neuroticism and job satisfaction. As can be noted in Figure 2, the standardized regression coefficients between neuroticism
Onwards, using SPSS, correlations between all research variables have been determined. The results are available in Table 2. 


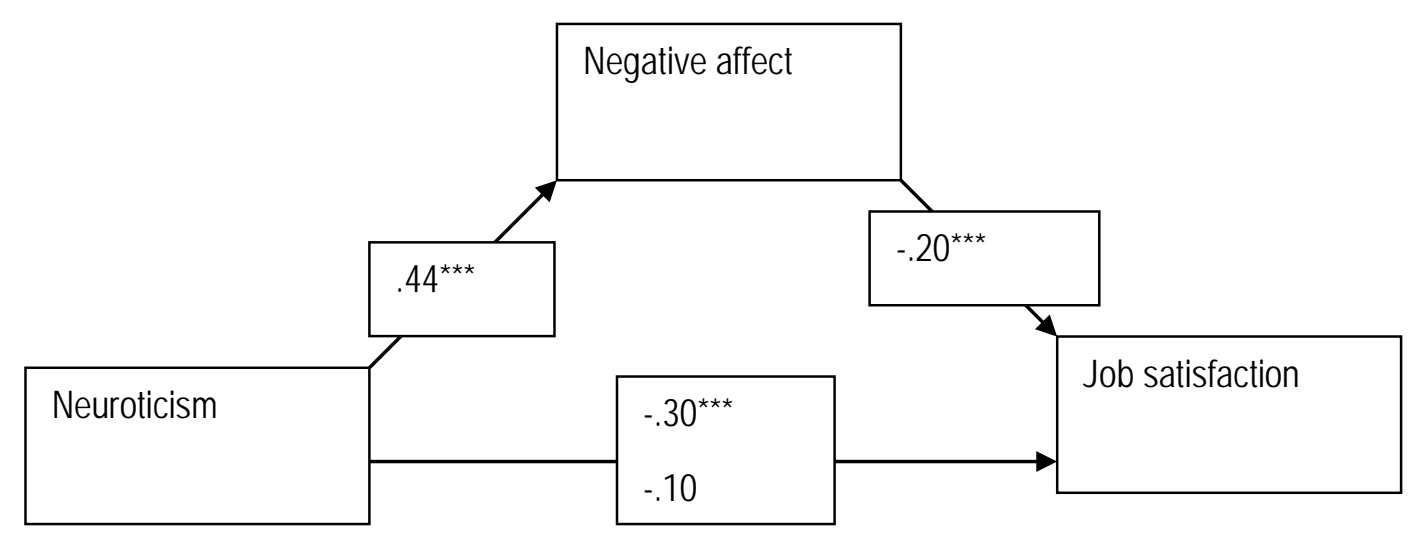

Figure 2. Negative affect as mediator

For the second hypothesis, we have analyzed the mediator effect of positive affect, on the relationship between neuroticism and job satisfaction. As can be noted from Fig. 3 , the standardized regression coefficients between neuroticism and positive affect, as well as between positive affect and job satisfaction are statistically significant. The indirect standardized effect is $(-.40)(.25)=-.1$. The significance of the indirect effect has further been tested through bootstrapping, and it was determined that the standardized indirect effect is -.35 and the confidence interval between -.137 and .009. We can therefore conclude that the indirect effect is statistically significant, and the mediation is a partial one.

Table 4. The mediator effect of positive affect to the relationship between neuroticism and job satisfaction

\begin{tabular}{llllll}
\hline Relation & Mediator & $\begin{array}{l}\text { Total } \\
\text { Effect }\end{array}$ & $\begin{array}{l}\text { Direct } \\
\text { Effect }\end{array}$ & $\begin{array}{l}\text { Indirect Effect } \\
\text { (95\% Lower - Upper) }\end{array}$ & $\%$ \\
\hline Neuroticism - Job satisfaction & Afect negativ & -.29 & .10 & $.001(-.137-.009)$ & 66.2 \\
\hline
\end{tabular}

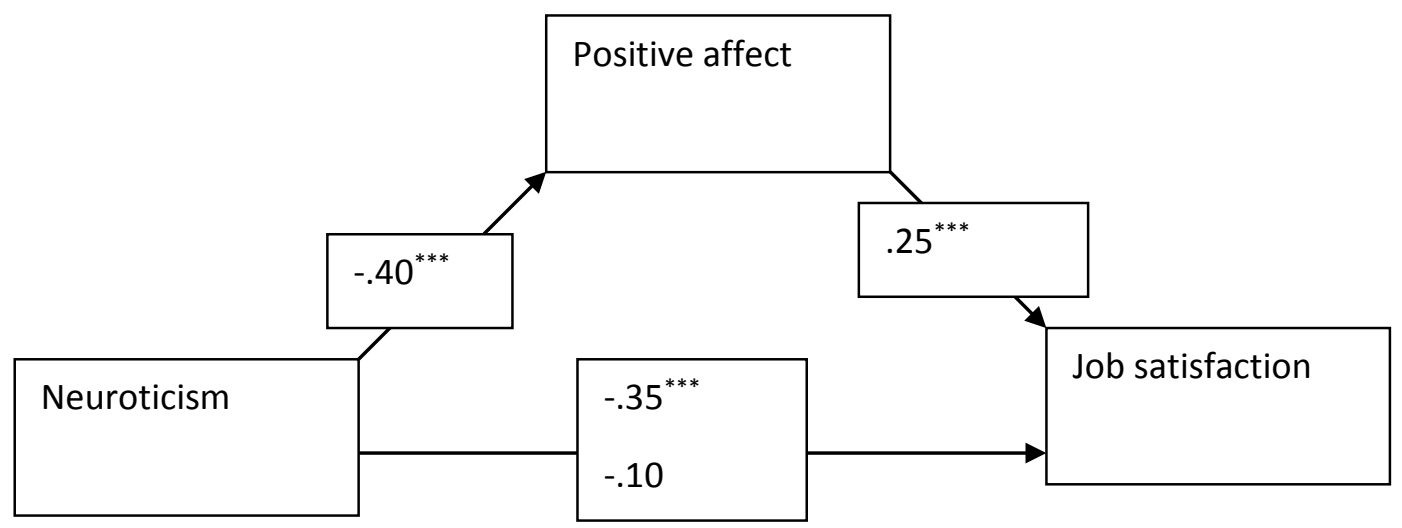

Figure 3. Negative affect as mediator

\section{DISCUSSION}

The main objective of this study has been furthering our understanding of the aspects which impact job satisfaction, through researching the influence of personality. Thus, the mediating effects of positive and negative affect on the relationship between neuroticism and job satisfaction have been tested. The study underlines the importance of the role of affect in regards to job satisfaction.

The results concerning the first hypothesis are in accordance with previous studies and with the scientific literature, namely that people with a high level of neuroticism 
tend to engage in those situations which lead to them experiencing negative affect (Magnus, Diener, Fujita, \& Pavot, 1993). Studies show that people with a high level of neuroticism tend to report experiencing a high number of negative life events. The explanation to this finding may be that neurotics tend to react in a negative manner to a larger variety of occurrences, compared to other individuals (Magnus, Diener, Fujita, \& Pavot, 1993). Furthermore, as shown in the scientific literature, a high negative affect correlates to a low level of happiness, as well as with a tendency to focus on the negative aspect of things. When this is encountered at the workplace or in professional contexts, a decrease in job satisfaction occurs (Judge, Heller \& Mount, 2002).

Furthermore, as seen in the introduction of this study, job satisfaction is an attitude and not an emotional state. The most common conceptualization, from an attitude perspective, is that job satisfaction is the subjective assessment of an individual's work, and is influenced by the affective work events (Weiss, 2002), as well as the emotional state a person has when evaluating (Brief, Butcher \& Robertson, 1995). As stated previously, studies so far have established a connection between a high level of neuroticism and one's tendency to experience negative events. Moreover, in a professional context, neurotic individuals experience more negative emotions, which translate to negative workplace attitudes and an increased level of workplace stress (Birch \& Kamali, 2001). Considering the already established relationship between neuroticism and workplace satisfaction, we can conclude that the current study furthers the understanding of the mechanisms through which this relationship is expressed.

We can similarly report the second hypothesis. The statistically significant, negative correlation between neuroticism and positive affect has been described in previous studies. Individuals with a low level of neuroticism tend to experience a positive disposition, and to perceive life contexts as favourable and desirable (Lyubomirsky et al., 2005). They tend to be more calm, more emotionally stable and not to have persistent negative moods (Brief, 1998). Additionally, previous research shows a direct correlation between positive affect and the frequency of desirable events (Clark \& Watson, 1988). When these events are related to the workplace, they lead to a rise in job satisfaction.

That the mediating effect of negative affect is a total one, and that of the positive affect only a partial one is not surprising. Although the mechanisms through which these relationships express are similar, it seems that the frequency of negative affect acts more strongly as a predictor of work satisfaction, compared to the intensity of positive affect, when one experiences it (Fisher, 2000).
This paper contributes to the industrial organizational psychology literature, illustrating possible mechanisms through which personality influences job satisfaction, introducing the importance of affect. Although the scientific literature has focused quite intensely on this topic, so far the mechanisms through which this relationship appears were unclear. This study was meant to shed some light in this area, and has somewhat achieved its purpose, providing an explanation which centers on these two aspects, affect, and tries to explain the way in which it moderates the initial relationship.

Besides these modest theoretical implications, this study also relates to the latest practices in the $1 / 0$ psychology. The latest studies have strongly linked job satisfaction to performance, suggesting that a happy and satisfied employee is a productive and high-performing one (Organ \& Ryan, 1995). Moreover, behavioural relationships at the workplace have been studied, such as organizational citizenship behaviour, absenteeism and turnover intention (Thirulogasundaram \& Sahu, 2014), lateness, substance abuse and early retirement (Hulin, 1991). Taking into consideration this understanding about job satisfaction, it is important to understand the mechanisms through which it occurs, in order to further generate interventions regarding the way in which people experience feelings and emotions in the workplace, as well as regarding the way in which they align with work events.

\section{Limitations and further directions}

The obtained results, however significant, should be viewed critically, because this research is not free of limitations. Firstly, the research design is cross-sectional, and thus it cannot include any cause-effect types of relationships. However, this study collected self-report data, on a narrow sample. Perhaps a larger total of participants would have yielded more subtle differences. The predominance of female participants (83\%) must also be taken into account, given that neuroticism levels are know to be slightly, albeit significantly, higher for women than for men (Costa, Terracciano \& McCrae, 2001).

Limitations can also be found at the level of the participant's professions. All 117 participants included in this research are TESA personnel. In order to gain a more comprehensive picture, future studies should include employees working on the operational level as well, to ensure a better coverage of the work field.

For a better understanding of the links between personality and job satisfaction, future studies could consider the mediator effect of the two types of affect, positive and negative, simultaneously. Another research line could be the study of job satisfaction, not from the perspective of the global construct, but from each of its particular facets, both 
internal and external. Moreover, a „peer review” kind of approach is recommended, so as to exceed the limits imposed by self-report methods.

\section{REFERENCES}

Arvey, R. D., Bouchard, T. J., Segal, N. L., \& Abraham, L. M. (1989). Job satisfaction: Environmental and genetic components. Journal of Applied Psychology, 74(2), 187.

Barrick, M. R., \& Mount, M. K. (1991). The big five personality dimensions and job performance: a metaanalysis. Personnel psychology, 44(1), 1-26.

Bowling, N. A., Eschleman, K. J., \& Wang, Q. (2010). A meta-analytic examination of the relationship between job satisfaction and subjective well-being. Journal of Occupational and Organizational Psychology, 83(4), 915934.

Brief, A. P. (1998). Attitudes in and around organizations. Thousand Oaks, CA: Sage.

Brief, A. P., Butcher, A. H., \& Roberson, L. (1995). Cookies, disposition, and job attitudes: The effects of positive moodinducing events and negative affectivity on job satisfaction in a field experiment. Organizational Behavior and Human Decision Processes, 62(1), 55-62.

Caroll, B. (1973). Job Satisfaction A review of the Literature. Cornell University, Ithaca, New York State.

Cheng, H., \& Furnham, A. (2003). Personality, self-esteem, and demographic predictions of happiness and depression. Personality and individual differences, 34(6), 921-942.

Cloninger, C. R. (2004). Feeling good: the science of wellbeing. Oxford University Press.

Connolly, J. J., \& Viswesvaran, C. (2000). The role of affectivity in job satisfaction: A meta-analysis. Personality and individual differences, 29(2), 265-281.

Costa Jr, P., Terracciano, A., \& McCrae, R. R. (2001). Gender differences in personality traits across cultures: robust and surprising findings.

Costa, P. T., \& McCrae, R. R. (1992). Four ways five factors are basic. Personality and individual differences, 13(6), 653665.

Costa, P. T., McCrae, R. R., \& Dye, D. A. (1991). Facet scales for agreeableness and conscientiousness: $A$ revision of the NEO Personality Inventory. Personality and individual Differences, 12(9), 887-898.
Costa, P. T., \& McCrae, R. R. (1985). The NEO personality inventory.

Costa, P. T., \& McCrae, R. R. (1980). Influence of extraversion and neuroticism on subjective well-being: happy and unhappy people. Journal of personality and social psychology, 38(4), 668.

DeNeve, K. M., \& Cooper, H. (1998). The happy personality: A meta-analysis of 137 personality traits and subjective wellbeing. Psychological Bulletin, 124(2), 197-229.

Diener, E., Ng, W., Harter, J., \& Arora, R. (2010). Wealth and happiness across the world: Material prosperity predicts life evaluation, whereas psychosocial prosperity predicts positive feeling. Journal of Personality and Social Psychology, 99(1), 52-61. doi:10.1037/a0018066.

Diener, E. D., Emmons, R. A., Larsen, R. J., \& Griffin, S. (1985). The satisfaction with life scale. Journal of personality assessment, 49(1), 71-75.

Dormann, C., \& Zapf, D. (2001). Job satisfaction: A metaanalysis of stabilities. Journal of organizational behavior, 22(5), 483-504.

Elliot, A. J., \& Thrash, T. M. (2002). Approach-avoidance motivation in personality: approach and avoidance temperaments and goals. Journal of personality and social psychology, 82(5), 804.

Fisher, C. D. (2000). Mood and emotions while working: Missing pieces of job satisfaction? Journal of Organizational Behavior, 21, 185-202

Frye, C. M. (1996). New evidence for the job characteristics model: A meta-analysis of the job characteristics-job satisfaction relationship using composite correlations. Eleventh Annual Meeting of the Society for Industrial and Organizational Psychology, San Diego, CA.

Furnham, A., \& Cheng, H. (1999). Personality as predictor of mental health and happiness in the East and West. Personality and Individual Differences, 27(3), 395403.

Gale, C. R., Booth, T., Mttus, R., Kuh, D., \& Deary, I. J. (2013). Neuroticism and extraversion in youth predict mental wellbeing and life satisfaction 40 years later. Journal of Research in Personality, 47, 687-697. 
Hackman, J.R. and Greg R. Oldham (1976). Motivation through the design of work: Test of a theory. Organisational Behaviour and Human Performance, 16, 250-79.

Hulin, C. L. (1991). Adaptation, persistence, and commitment in organi- zations. In M. D. Dunnette \& L. M. Hough (Eds.), Handbook of industrial and organizational psychology (2nd ed., pp. 443-505). Palo Alto, CA: Consulting Psychologists Press.

laffaldano, M. T., \& Muchinsky, P. M. (1985). Job satisfaction and job performance: A meta-analysis. Psychological Bulletin, 97, 251-273.

Judge, T. A., Parker, S., Colbert, A. E., Heller, D., \& llies, R. (2001). Job satisfaction: A cross-cultural review. Handbook of industrial, work and organizational psychology, 2, 25-52.

Judge, T. A., Bono, J. E., \& Locke, E. A. (2000). Personality and job satisfaction: The mediating role of job characteristics. Journal of Applied Psychology, 85, 237-249.

Judge, T. A., Parker, S., Colbert, A. E., Heller, D., \& llies, R. (2001). Job satisfaction: A cross-cultural review. Handbook of industrial, work and organizational psychology, 2, 25-52.

Judge, T. A., Higgins, C. A., Thoresen, C. J., \& Barrick, M. R. (1999). The big five personality traits, general mental ability, and career success across the life span. Personnel psychology, 52(3), 621-652.

Judge, T. A., Heller, D., \& Mount, M. K. (2002). Five-factor model of personality and job satisfaction: a meta-analysis.

Judge, T. A., Thoresen, C. J., Bono, J. E., \& Patton, G. K. (1998). The job satisfaction-job performance relationship: 1939-1998. In annual meeting of the Academy of Management, San Diego, CA.

Jurgensen, C. E. (1978). Job preferences (What makes a job good or bad?). Journal of Applied Psychology, 63, 267276.

Keyes, C. L., Shmotkin, D., \& Ryff, C. D. (2002). Optimizing well-being: the empirical encounter of two traditions. Journal of personality and social psychology, 82(6), 1007.

Kline, R. B. (2011). Principles and practice of structural equation modeling (3rd Ed.). New York: IL: The Guilford Press.

Levin, I., \& Stokes, J. P. (1989). Dispositional approach to job satisfaction: Role of negative affectivity. Journal of applied psychology, 74(5), 752.

Linley, P. A., Maltby, J., Wood, A. M., Osborne, G., \& Hurling, R. (2009). Measuring happiness: The higher order factor structure of subjective and psychological well-being measures. Personality and Individual Differences, 47(8), 878-884.

Locke, E. A. 1976. The nature and causes of job satisfaction. In M. D. Dunnette (Ed.), Handbook of industrial and organizational psychology, 1297-1343. Chicago: Rand McNally

Lucas, R. E., \& Baird, B. M. (2004). Extraversion and emotional reactivity. Journal of personality and social psychology, 86(3), 473.

Lucas, R. E., \& Diener, E. (2008). Subjective wellbeing. Handbook of emotions, 471-484.

Lyubomirsky, S. (2001). Why are some people happier than others? The role of cognitive and motivational processes in well-being. American psychologist, 56(3), 239.

Lyubomirsky, S., King, L., \& Diener, E. (2005). The benefits of frequent positive affect: Does happiness lead to success?.

Magnus, K., Diener, E., Fujita, F., \& Pavot, W. (1993). Extraversion and neuroticism as predictors of objective life events: a longitudinal analysis. Journal of personality and social psychology, 65(5), 1046.

McCullough, M. E., Bellah, C. G., Kilpatrick, S. D., \& Johnson, J. L. (2001). Vengefulness: Relationships with forgiveness, rumination, well-being, and the Big Five. Personality and Social Psychology Bulletin, 27(5), 601610.

McDowell, I., 2010. Measures of self-perceived well-being. Journal of Psycho-somatic Research 69, 69-79.

McKennel, A. C., \& Andrews, F. M. (1980). Models of cognition and affect in perceptions of well- being. Social Indicators Research, 8, 127-155.

Meyer, G. J., \& Shack, J. R. (1989). Structural convergence of mood and personality: Evidence for old and new directions. Journal of personality and social psychology, 57(4), 691.

Naragon, K., \& Watson, D. (2009). Positive affectivity.

Near, J. P., Rice, R. W., \& Hunt, R. G. (1987). Job satisfaction and life satisfaction: A profile analysis. Social Indicators Research, 19(4), 383-401.

Near, J. P., \& Rechner, P. L. (1993). Cross-cultural variations in predictors of life satisfaction: An historical view of differences among West European countries. Social indicators research, 29(1), 109-121.

Newbury-Birch, D., \& Kamali, F. (2001). Psychological stress, anxiety, depression, job satisfaction, and personality 
characteristics in preregistration house officers. Postgraduate Medical Journal, 77(904), 109-111.

$\mathrm{Ng}, \mathrm{W}$. (2009). Clarifying the relation between neuroticism and positive emotions. Personality and Individual Differences, 47(1), 69-72.

Organ, D. W., \& Ryan, K. (1995). A meta-analytic review of attitudinal and dispositional predictors of organizational citizenship behavior. Personnel psychology, 48(4), 775-802.

Petty, R. E., Wegener, D. T., \& Fabrigar, L. R. (1997). Attitudes and attitude change. Annual review of psychology, 48(1), 609-647.

Reisenzein, R., \& Schönpflug, W. (1992). Stumpf's cognitive-evaluative theory of emotion. American Psychologist, 47(1), 34.

Roberts, B. W., \& Mroczek, D. (2008). Personality trait change in adulthood. Current directions in psychological science, 17(1), 31-35.

Rode, J. C. (2004). Job satisfaction and life satisfaction revisited: A longitudinal test of an integrated model. Human Relations, 57(9), 1205-1230.

Saari, L. M., \& Judge, T. A. (2004). Employee attitudes and job satisfaction. Human resource management, 43(4), 395407.

Salancik, G. R., \& Pfeffer, J. (1978). A social information processing approach to job attitudes and task design. Administrative science quarterly, 224-253.

Saris, W. E. \& Andreenkova, A. (2001). Following changes in living conditions and happiness in post communist Russia: The Russet Panel. Journal of Happiness Studies 2, 95-109.

Shin, D. C. \& Johnson. D. M. (1978). Avowed happiness as an overall assessment of the quality of life. Social fndicarors Rewarch. 5. 475492.

Smith, F., Roberts, K. H., \& Hulin, C. L. (1976). Ten year job satisfaction trends in a stable organization. Academy of Management Journal, 19(3), 462-469.

Smith, P. C., Kendall, L. M., \& Hulin, C. L. (1969). The measurement of satisfaction in work and retirement. Chicago: Rand McNally

Smith, T. W., \& MacKenzie, J. (2006). Personality and risk of physical illness. Annu. Rev. Clin. Psychol., 2, 435-467.

Smith-Lovin, L. (1991). An affect control view of cognition and emotion. In J. A. Howard \& P. L. Callero (Eds.), The selfsociety dynamic: Cognition, emotion, and action (pp. 143169). New York: Cambridge Univ. Press.
Staw, B. M., Bell, N. E., \& Clausen, J. A. (1986). The dispositional approach to job attitudes: A lifetime longitudinal test. Administrative Science Quarterly, 56-77.

Staw, B. M., \& Ross, J. (1985). Stability in the midst of change: A dis- positional approach to job attitudes. Journal of Applied Psychology, 70, 469-480.

Suh, E., Diener, E., \& Fujita, F. (1996). Events and subjective well-being: only recent events matter. Journal of personality and social psychology, 70(5), 1091.

Suls, J., \& Bunde, J. (2005). Anger, anxiety, and depression as risk factors for cardiovascular disease: the problems and implications of overlapping affective dispositions. Psychological bulletin, 131(2), 260.

Tellegen, A. (1985). Structures of mood and personality and their relevance to assessing anxiety, with an emphasis on self-report.

Thirulogasundaram, V. P., \& Sahu, P. C. (2014). Job satisfaction and absenteeism interface in Corporate SectorA study. Journal of Humanities and Social Science (IOSRJHSS), 19, 64-68.

Tokar, D. M., Fischer, A. R., \& Subich, L. M. (1998). Personality and vocational behavior: A selective review of the literature, 1993-1997. Journal of Vocational Behavior, 53(2), 115-153.

Watson, D., \& Clark, L. A. (1999). The PANAS-X: Manual for the positive and negative affect schedule-expanded form.

Watson, D., Clark, L. A., \& Tellegen, A. (1988). Development and validation of brief measures of positive and negative affect: the PANAS scales. Journal of personality and social psychology, 54(6), 1063.

Watson, D., Clark, L. A., \& Harkness, A. R. (1994). Structures of personality and their relevance to psychopathology. Journal of abnormal psychology, 103(1), 18.

WERNIMONT, P. F. Intrinsic and extrinsic factors in job satisfaction. Journal of Applied Psychology, 1966, 50, 4150.

Wu, C. H., Tsai, Y. M., \& Chen, L. H. (2009). How do positive views maintain life satisfaction?. Social Indicators Research, 91(2), 269-281. 